\title{
PENGARUH LATIHAN SKIPPING TERHADAP PENINGKATAN CARDIOVASCULAR ENDURANCE PADA ANAK USIA SEKOLAH 10-12 TAHUN DI SDN PLUMBON 02 KECAMATAN SURUH KABUPATEN SEMARANG
}

\author{
Silvia Rahmawati*) ; Budiyati ; Nina Indriyawati \\ Jurusan Keperawatan; Poltekkes Kemenkes Semarang \\ Jl. Tirto Agung ; Pedalangan ; Banyumanik ; Semarang
}

\begin{abstract}
Abstrak
Saat ini, banyak anak dan orang tua mengabaikan tentang pentingnya olahraga bagi kebugaran jasmani dan daya tahan jantung. Cardiovascular endurace yang baik akan meningkatkan kemampuan kerja anak dengan intensitas lebih besar dan waktu lebih lama tanpa kelelahan. Tujuan penelitian ini adalah untuk mendeskripsikan pengaruh latihan skipping terhadap peningkatan cardiovascular endurance pada anak usia sekolah 10-12 tahun. Jenis penelitian yang digunakan adalah Pra-Eksperimental dengan desain penelitian one group pre test dan post test. Sampel terdiri dari 21 orang anak usia sekolah 10 - 12 tahun yang dipilih menggunakan teknik purposive sampling. Seluruh sampel diberikan latihan skipping sebanyak 8 kali dalam waktu 10 menit setiap pertemuan dan dilaksanakan pada pagi hari antara pukul 07.00 - 09.00 WIB. Pelaksanaan pre-test dan post-test menggunakan Rockport Walking Fitness Test untuk menilai cardiovaskular endurance. Hasil uji beda simple paired $t$-test menunjukkan bahwa terdapat perbedaan antara data pre-test dan post-test dengan $\mathrm{p}$ value $=0.000$ dan $\mathrm{t}=5,362$. Sehingga dapat disimpulkan terdapat pengaruh latihan skipping terhadap peningkatan cardiovascular endurance pada anak usia sekolah 10-12 tahun.
\end{abstract}

Kata Kunci : Cardiovascular endurance ; Latihan skipping ; Rockport Walking Fitness Test

\begin{abstract}
[THE INFLUENCE OF SKIPPING EXCERSICE TO INCREASED CARDIOVASCULAR ENDURANCE ON SCHOOL AGE CHILDREN 10-12 YEARS IN ELEMENTARY SCHOOL PLUMBON 02 SURUH SUB -DISTRICT SEMARANG REGENCY] The current phenomena, many children and parents who ignore the importance of sports to physical fitness and endurance of the heart. Cardiovascular endurace which will both improve the working abilities of the child with greater intensity and longer without fatigue. The purpose of this research was to describe the influence of skipping exercise to increased cardiovascular endurance on school age children 10-12 years. The type of research used was pre-experimental research designs with one group pre-post test. The sample consists of 21 children of school age $10-12$ years old. The entire sample was given skipping workouts as much as 8 times within 10 minutes of each meeting and implemented in the morning between $07.00-09.00 \mathrm{pm}$. The implementation of the pretest and post test using Rockport Walking Fitness Test to assess cardiovaskular endurance. The results of the analysis of simple paired $t$-test showed that there is a difference between data pre-test and post test with $\mathrm{p}$ value $=0000$. There was an influence of skipping exercise to increased cardiovascular endurance on school age children 10-12 years.
\end{abstract}

Keywords : Cardiovascular endurance ; Rockport walking fitness test ; Skipping exercise

*) Penulis Korespondensi

Email : silvia.rahma1995@gmail.com 


\section{Pendahuluan}

Anak usia sekolah adalah anak pada usia 6-12 tahun. Di dalam hidup ini, kebutuhan dasar anak untuk tumbuh kembang, secara umum digolongkan menjadi 3 kebutuhan dasar yaitu ASUH, ASIH, ASAH. Salah satu komponen kebutuhan ASUH (kebutuhan fisikbiomedis) yang dibutuhkan anak adalah kebugaran jasmani yang baik (Soetjiningsih, 2014). Kebugaran jasmani penting dimiliki oleh anak usia sekolah karena pada masa ini anak telah memasuki dunia pendidikan di sekolah dimana anak akan dipadati dengan berbagai aktivitas baik di lingkungan rumah, lingkungan sekolah, maupun lingkungan sekitar tempat tinggal. Sehingga, kondisi kesehatan jasmani yang sehat akan bermanfaat untuk menunjang kapasitas kerja fisik anak yang pada akhirnya bisa belajar dan bermain untuk jangka waktu lebih la ma dan diharapkan prestasi anak meningkat (Agustini, 2007). Salah satu komponen penting dalam peningkatan kebugaran jasmani yaitu daya tahan kardiovaskular.

Daya tahan kardiovaskular yang baik akan meningkatkan kemampuan kerja anak dengan intensitas lebih besar dan waktu lebih lama tanpa kelelahan (Nabi T, 2015). Daya tahan kardiovaskular (Cardiovascular endurace) merupakan kapasitas keseluruhan dan kemampuan sistem kardiovaskular dan pernapasan untuk melaksanakan latihan berat yang berkepanjangan. Cardiovascular endurace diukur melalui kadar $\mathrm{VO}_{2}$ max yang dicapai. Semakin tinggi kadar $\mathrm{VO}_{2}$ max maka semakin tinggi pula cardiovascular endurace yang dimiliki individu tersebut. Cara yang digunakan untuk pengukuran $\mathrm{VO}_{2}$ max yaitu test daya tahan jantung dengan melibatkan aktivitas fisik seperti rockport walking fitness test, cooper test, multi-stage test dan lainnya. Tes tersebut tentunya melibatkan aktivitas fisik yang berat. (Muhajir, 2007).

Cara untuk meningkatkan cardiovascular endurace tersebut adalah dengan melakukan aktivitas fisik dan berolahraga secara teratur. Aktivitas fisik yang kurang merupakan satu dari sepuluh faktor risiko utama kematian di seluruh dunia. Rendahnya kebugaran jasmani adalah faktor risiko utama dari penyakit tidak menular (Non-communicable disease) seperti penyakit jantung, kanker dan diabetes (WHO, 2015). Ada banyak latihan fisik untuk meningkatkan cardiovascular endurace, akan tetapi tidak semua latihan tersebut sesuai diberikan kepada anak-anak. Pada anak usia sekolah sangat erat hubungannya dengan permainan dan bermain. Aktivitas jasmani yang didesain dengan model permainan akan menjadi sarana yang tepat untuk memenuhi kebutuhan anak terhadap peningkatan cardiovascular endurance (Tonang, 2014). Salah satunya jenis permainan yang melibatkan aktivitas fisik di dalamnya yaitu skipping (lompat tali). Skipping tentunya sudah familiar di kalangan anak. Seringkali anak-anak bermain lompat tali dengan 2-3 orang anak. Ternyata permainan ini memiliki manfaat yang besar bagi peningkatan cardiovascular indurance (Fandy, 2010).

Pada anak usia sekolah diperlukan daya tahan jantung yang baik agar tidak mudah letih saat menjalani aktivitas. Namun, pada fenomena saat ini, banyak anak dan orang tua yang mengabaikan tentang pentingnya olahraga bagi kebugaran jasmani dan daya tahan jantung. Pada kenyataannya anak selalu dipadati dengan kegiatan yang sebagian besar berhubungan dengan kognitif maupun afektif, sedangkan kegiatan yang berhubungan dengan psikomotor diabaikan. Di jaman maju seperti ini dan diiringi perkembangan teknologi, anak lebih suka memainkan permainan di gadget, playstation, komputer atau internet daripada melakukan permainan aktivitas fisik bersama teman sebaya. Akibatnya banyak anak yang kurang bergerak karena hanya duduk diam di depan gadget, televisi atau komputer (Ayu, 2016). Hal ini dibuktikan dengan data menurut WHO (2016), di negara-negara berpenghasilan tinggi terdapat $26 \%$ pria dan $35 \%$ wanita yang kurang aktivitas fisik, sedangkan di negara berpenghasilan rendah terdapat $12 \%$ pria dan $24 \%$ wanita yang kurang aktif secara fisik. Dari data di atas menunjukkan semakin membuat lemahnya kualitas dalam hal cardiovascular endurace.

Pada penelitian yang dilakukan oleh Nurul (2016) dapat dilihat mengenai pentingnya cardiovasculer endurance untuk 
meningkatkan stamina dan mencegah mudahnya mengalami kelelahan saat menjalani aktivitas yang berat. Selain itu, latihan aktivitas fisik secara teratur dapat meningkatlan nilai hal cardiovascular endurace Melihat pentingnya kebugaran jasmani dalam hal cardiovascular indurance pada anak, kita sebagai perawat tentunya juga berperan dalam memenuhi kebutuhan dasar anak tersebut. Hal ini dikarenakan pelayanan keperawatan anak berorientasi pada upaya pencegahan penyakit dan peningkatan derajat kesehatan, bukan hanya mengobati anak yang sakit. Upaya pencegahan penyakit dan peningkatan derajat kesehatan bertujuan untuk menurunkan angka kesakitan dan kematian pada anak. Sehingga, tujuan dari penelitian ini adalah untuk mengetahui pengaruh latihan skipping terhadap peningkatan cardiovascular endurance pada anak usia sekolah 10-12 tahun.

\section{Metode}

Penelitian ini adalah jenis penelitian pre-eksperimental design dengan desain penelitian one group pre test dan post test (Notoatmodjo, 2010). Populasi dalam penelitian ini adalah seluruh siswa kelas $\mathrm{V}$ dan kelas VI SDN Plumbon 02 yang berusia 10-12 tahun berjumlah 42 orang. Teknik sampling menggunakan teknik non random (non probability sampling) yang menggunakan teknik purposive sampling dengan mengacu pada kriteria inklusi dan eksklusi (Sora, 2016). Sampel dalam penelitian ini berjumlah 21 orang. Instrumen yang digunakan dalam penelitian ini yaitu alat skipping, lintasan sepanjang 1 mil / 1,6 km / 1609 meter, stopwatch, lembar catatan, metronome.

Dalam melaksanakan penelitian ini, peneliti melakukan 8 kali pertemuan. Pre-test dilaksanakan sebelum sesi pertama dimulai dan post-test dilakukan setelah pertemuan yang terakhir ke-8. Pre dan post test dilakukan dengan menggunakan Rockport Walking Fitness Tes (tes lari/jalan : 1 mil / 1,609 meter) untuk mengukur perbandingan nilai $\mathrm{VO}_{2} \max$ (Mackenzie, 2016) Data hasil test diolah menggunakan rumus Kline :
$132.853-(0.0769 \times$ Weight $)-(0.3877 \times$ Age $)+$ $(6.315 \times$ Gender $)-(3.2649 \times$ Time $)-(0.1565 \times$ Heart rate)

Selanjutnya data hasil pre dan post test dilakukan uji beda menggunakan uji statistik simple paired t-test.

\section{Hasil Penelitian dan Pembahasan}

Tabel 1.

Distribusi frekuensi responden berdasarkan jenis kelamin, usia dan berat badan di SD Negeri Plumbon $02(n=21)$

\begin{tabular}{ccc}
$\begin{array}{c}\text { Karakteristik } \\
\text { Responden }\end{array}$ & Frekuensi & $\begin{array}{c}\text { Persen } \\
(\%)\end{array}$ \\
\hline $\begin{array}{c}\text { Jenis Kelamin } \\
\text { Laki-laki }\end{array}$ & 9 & 42,9 \\
Perempuan & 12 & 57,1 \\
Usia (tahun) & & \\
10 & 11 & 52,4 \\
11 & 5 & 23,8 \\
12 & 5 & 23,8 \\
Berat Badan $(\mathrm{kg})$ & Mean & SD \\
$21-30$ & 26,8 & 2,3 \\
$31-40$ & 35,8 & 3,02 \\
$>40$ & 43,5 & 3,54 \\
\hline
\end{tabular}

Jumlah responden pada penelitian ini terdiri dari 9 orang laki-laki dan 12 orang perempuan. Perbedaan jenis kelamin juga menentukan nilai cardiovasculer endurance. Umumnya laki-laki memiliki level lebih tinggi $40-60 \%$ dibandingkan perempuan. Level cardiovasculer endurance seorang lakilaki yang tidak aktif berolahraga adalah 47 $\mathrm{ml} / \mathrm{kg} /$ menit, dan bagi perempuan yang tidak aktif berolahraga rata-rata sebesar 38 $\mathrm{ml} / \mathrm{kg} / \mathrm{menit}$. Sehingga pemilihan responden dengan jenis kelamin berbeda digunakan untuk mengetahui perbedaan antara nilai cardiovascular endurance antara laki-laki dan perempuan (Aris, 2015). Selain jenis kelamin, pemilihan responden juga dipilih berdasarkan usia. Pada penelitian ini, diambil responden anak berusia 10-12 tahun (usia anak sekolah akhir), dikarenakan jika dilihat dari tahap perkembangan fisik, kognitif dan psiko sosial, usia anak sekolah akhir 10-12 tahun memiliki tahap perkembangan yang menunjang dalam pengukuran cardiovasculer endurance. Perkembangan otot dan tungkai lebih kuat, daya tahan tubuh makin kuat, dan kemampuan untuk menerima teori yang diberikan lebih baik (Soetjiningsih, 2014). 
Karakteristik responden yang ketiga yaitu berat badan. Jika dilihat dari sisi berat badan, responden memiliki berat badan dengan rentang $21-50 \mathrm{~kg}$. Berat badan tentu saja sangat mempengaruhi nilai cardiovasculer endurance karena pada kasus kelebihan berat badan berpengaruh terhadap fungsi sistem sistem kardiovaskuler dan sistem respirasi (kardio respirasi). Kelebihan berat badan tersebut dikaitkan dengan peningkatan jumlah jaringan lemak. Lemak ini meningkatkan jumlah penumpukan plak dalam arteri yang menyebabkan saluran arteri menyempit sehingga meningkatkan resistensi perifer yang berakibat peningkatan tekanan darah dan kerusakan pembuluh darah yang berpengaruh terhadap penurunan kerja sistem kardiovaskuler dan sistem respirasi (Reny, 2012).

Tabel 2.

Distribusi nilai cardiovasculer endurance berdasarkan jenis kelamin sebelum latihan skipping $(n=21)$

\begin{tabular}{lcccc}
\hline $\begin{array}{c}\text { Jenis } \\
\text { Kelamin }\end{array}$ & $\begin{array}{c}\text { Minimum } \\
(\mathrm{ml} / \mathrm{kg} / \\
\text { menit) }\end{array}$ & $\begin{array}{c}\text { Maksimum } \\
(\mathrm{ml} / \mathrm{kg} / \\
\text { menit })\end{array}$ & Mean & SD \\
\hline Laki-laki & 37,88 & 50,86 & 45,91 & 4,13 \\
Perempuan & 35,72 & 43,9 & 39,9 & 2,62 \\
\hline
\end{tabular}

Tabel 3.

Distribusi nilai cardiovasculer endurance sebelum latihan skipping $(n=21)$

\begin{tabular}{lcccc}
\hline $\begin{array}{c}\text { Cardivasculer } \\
\text { Endurance } \\
(\mathrm{ml} / \mathrm{kg} / \mathrm{menit})\end{array}$ & $\begin{array}{c}\text { Minimum } \\
(\mathrm{ml} / \mathrm{kg} / \\
\text { menit })\end{array}$ & $\begin{array}{c}\text { Maksimum } \\
(\mathrm{ml} / \mathrm{kg} / \\
\text { menit })\end{array}$ & Mean & SD \\
\hline Pre test & 35,75 & 50,86 & 42,53 & 4,43 \\
\hline
\end{tabular}

Pada pemeriksaan pre-test,

didapatkan hasil jika sebelum dilakukan latihan skipping, nilai rata-rata cardiovasculer endurance anak laki-laki sebesar 45,91 $\mathrm{ml} / \mathrm{kg} /$ menit dengan nilai minimum 37,88 $\mathrm{ml} / \mathrm{kg} /$ menit dan nilai maksimum 50,86 $\mathrm{ml} / \mathrm{kg} /$ menit. Sementara rata-rata nilai pada anak perempuan sebesar $39,9 \mathrm{ml} / \mathrm{kg} /$ menit dengan nilai minimum $35,72 \mathrm{ml} / \mathrm{kg} /$ menit dan anak maksimum $43,9 \mathrm{ml} / \mathrm{kg} /$ menit.

Selanjutnya, keseluruhan nilai ratarata cardiovasculer endurance anak usia $10-12$ tahun di SDN Plumbon 02 adalah 42,53 $\mathrm{ml} / \mathrm{kg} / \mathrm{menit}$, dengan nilai minimum yaitu $35,75 \mathrm{ml} / \mathrm{kg} /$ menit dan nilai maksimum sebesar 50,86 ml $/ \mathrm{kg} /$ menit. Dari hasil pretest, terutama jika dilihat dari nilai minimum, dapat dikatakan jika nilai cardiovasculer endurance responden masih rendah. Dikarenakan nilai normal pada anak usia 10 - 19 tahun yaitu $47-56 \mathrm{ml} / \mathrm{kg} /$ menit bagi lagi-laki dan $38-46 \mathrm{ml} / \mathrm{kg} /$ menit bagi perempuan.

Rendah tingginya nilai cardiovasculer endurance dikarenakan banyak faktor yang mempengaruhi diantaranya jenis kelamin, usia, berat badan, kondisi kesehatan, konsumsi obat-obatan, terpaparnya asap rokok dan latihan fisik harian yang dilakukan. Anak-anak dengan jenis kelamin laki-laki memiliki nilai cardiovasculer endurance yang lebih tinggi dari anak perempuan yaitu 40-60\% lebih tinggi (Faisal, 2015).

Lalu, anak dengan berat badan berlebih cenderung memiliki daya tahan jantung yang relatif rendah dibandingkan dengan anak yang memiliki berat badan normal. Selain itu, pengaruh kondisi kesehatan dan konsumsi obat-obatan yaitu pada anak yang sedang memiliki kondisi yang buruk dan efek samping yang timbul dari konsumsi obat akan mempengaruhi kerja metabolisme tubuh anak yang akan membuat anak tidak maksimal dalam menjalani pengukuran daya tahan jantung dan nilai cardiovasculer endurance menjadi rendah. Selanjutnya, anak yang tidak sering terpapar asap rokok akan memiliki kualitas sistem kardiorespirasi yang lebih bagus jika dibandingkan dengan anak yang sering terpapar asap rokok. Lalu, anak yang memiliki aktivitas fisik tinggi akan memiliki kebugaran jasmani yang baik sehingga cenderung memiliki nilai cardiovasculer endurance yang tinggi jika dibandingkan dengan anak yang memiliki aktivitas fisik yang rendah (Femina, 2016).

Tabel 4.

Distribusi nilai cardiovasculer endurance berdasarkan jenis kelamin sesudah latihan skipping $(n=21)$

\begin{tabular}{ccccc}
$\begin{array}{c}\text { Jenis } \\
\text { Kelamin }\end{array}$ & $\begin{array}{c}\text { Minimum } \\
\text { (ml/kg/ } \\
\text { menit) }\end{array}$ & $\begin{array}{c}\text { Maksimum } \\
\text { (ml/kg/ } \\
\text { menit) }\end{array}$ & Mean & SD \\
\hline Laki-laki & 46,49 & 54,89 & 50,66 & 2,86 \\
Perempuan & 37,93 & 46,11 & 42,21 & 2,16 \\
\hline
\end{tabular}


Tabel 5.

Distribusi nilai cardiovasculer endurance sesudah latihan skipping $(n=21)$

\begin{tabular}{ccccc}
$\begin{array}{c}\text { Cardivasculer } \\
\text { Endurance } \\
(\mathrm{ml} / \mathrm{kg} / \text { menit })\end{array}$ & $\begin{array}{c}\text { Minimum } \\
\text { (ml/kg/ } \\
\text { menit) }\end{array}$ & $\begin{array}{c}\text { Maksimum } \\
(\mathrm{ml} / \mathrm{kg} / \\
\text { menit })\end{array}$ & Mean & $S D$ \\
\hline Post test & 37,93 & 54,89 & 45,83 & 4,92 \\
\hline
\end{tabular}

Pada pemeriksaan post-test, didapatkan hasil nilai rata-rata cardiovasculer endurance anak laki-laki sebesar 50,66 $\mathrm{ml} / \mathrm{kg} /$ menit dengan nilai minimum 46,49 $\mathrm{ml} / \mathrm{kg} /$ menit dan nilai maksimum 50,86 $\mathrm{ml} / \mathrm{kg} /$ menit. Sementara rata-rata nilai pada anak perempuan sebesar $42,21 \mathrm{ml} / \mathrm{kg} /$ menit dengan nilai minimum $37,93 \mathrm{ml} / \mathrm{kg} /$ menit dan anak maksimum 46,11 ml/kg/menit.

Selanjutnya, keseluruhan nilai ratarata cardiovasculer endurance pada anak usia 10 - 12 tahun di SDN Plumbon 02 setelah diberikan perlakuan latihan skipping adalah $45,83 \mathrm{ml} / \mathrm{kg} /$ menit, dengan nilai minimum yaitu $37,93 \mathrm{ml} / \mathrm{kg} /$ menit dan nilai maksimum sebesar $54,89 \mathrm{ml} / \mathrm{kg} /$ menit.

Dari perbandingan nilai cardiovasculer endurance pre-test dan post-test didapatkan hasil selisih dari nilai rata-rata pre-test dan post-test yaitu $3,3 \mathrm{ml} / \mathrm{kg} /$ menit. Sehingga, terjadi kenaikan nilai cardiovasculer endurance setelah dilakukannya latihan skipping. Terjadinya peningkatan nilai cardiovaskular endurance setelah mendapat perlakuan selama $8 \mathrm{kali}$, hal ini disebabkan oleh karena latihan skipping merupakan latihan fisik yang apabila dilakukan secara berulang-ulang dengan menambah jumlah beban pekerjaannya. Latihan fisik seperti latihan skipping merupakan pemberian beban fisik pada tubuh secara teratur, sistematis, dan berkisinambungan melalui program latihan yang tepat.

Latihan skipping merupakan latihan aerobik. Pelatihan yang bersifat aerobik yang dilakukan secara teratur akan meningkatkan daya tahan kardiovaskuler dan dapat mengurangi lemak tubuh. Dengan melakukan latihan olahraga atau kegiatan fisik yang baik dan benar berarti seluruh organ dipicu untuk menjalankan fungsinya sehingga mampu beradaptasi terhadap setiap beban yang diberikan (Ayu, 2015).

Selain itu latihan interval intensitas tinggi memberikan efek fisiologis pada sistem kardiovaskuler yaitu melalui adaptasi jantung terhadap latihan interval yang diberikan. Pada saat melakukan latihan intensitas tinggi maka akan terjadi peningkatan sistem kardiorespirasi yaitu peningkatan kebutuhan oksigen di otot yang aktif. Peningkatan kekuatan otot pernapasan (otot inspirasi dan otot ekspirasi), berkaitan erat dengan peningkatan metabolisme energi di dalam mitokondria sel otot pernapasan yang aktif. Sel otot yang berkontraksi membutuhkan banyak ATP. Akibatnya otot yang dipakai dalam latihan intensitas tinggi membutuhkan lebih banyak oksigen $\left(\mathrm{O}_{2}\right)$ dan menghasilkan karbondioksida $\left(\mathrm{CO}_{2}\right)$.

Peningkatan kardiovaskuler juga terjadi dikarenakan terjadinya peningkatan denyut jantung saat latihan. Peningkatan denyut jantung saat latihan ini akan meningkatkan stroke volume. Peningkatan stroke volume dan peningkatan frekuensi jantung dapat menyebabkan peningkatan cardiac output yaitu volume darah yang dikeluarkan oleh kedua ventrikel per menit. Peningkatan ini disertai dengan vasodilatasi pembuluh darah untuk membawa oksigen ke otot yang aktif. Latihan intensitas rendah yang diselingi diantara latihan intensitas tinggi pada latihan interval membantu pembuangan metabolisme dari otot selama periode istirahat pada saat latihan interval intensitas tinggi sedang dilakukan oleh tubuh. Perubahan periode latihan yang dilakukan bergantian ini membantu tubuh meningkatkan volume dalam mengkonsumsi oksigen selama latihan. Oksigen yang menuju ke otot yang aktif ini kan menguraikan asam laktat menjadi energi kembali (Ayu, 2015).

Pengaruh skipping terhadap peningkatan daya tahan jantung yaitu saat melakukan aktivitas fisik tubuh akan melakukan metabolisme untuk menghasilkan energi yang diperlukan tubuh saat melakukan aktivitas. Dalam melakukan metabolisme, tubuh akan memerlukan oksigen yang digunakan sebagai bahan bakar metabolisme sehingga disebut sebagai metabolisme aerob. Semakin berat aktivitas fisik yang dilakukan, maka jantung akan dituntut untuk memompa darah dan menyalurkan oksigen ke jaringan secara besar. Meningkatnya kebutuhan oksigen juga 
akan membuat laju respirasi pada paru meningkat (Steven, 1016).

Ketika tubuh tidak biasa dengan aktivitas fisik yang berat, maka pompa darah jantung dan penyaluran oksigen ke jaringan tidak optimal sehingga dapat memunculkan metabolisme anareob yang memiliki efek samping dihasilkannya asam laktat yang akan membuat tubuh terasa lelah. Latihan skipping atau latihan fisik secara intensif dapat membuat tubuh dan jantung terbiasa dengan aktivitas fisik yang ringan hingga berat sekalipun sehingga akan membuat meningkatnya kapasitas paru serta jantung akan lebih efisien dalam memompa darah dan menyalurkan oksigen ke jaringan (Steven, 2016).

Selain itu, pemilihan waktu yang tepat juga menentukan kualitas latihan. Pada penelitian latihan skipping dilakukan pada pagi hari dikarenakan pada pagi hari produksi hormon serotonin yang merupakan hormon peningkat mood dihasilkan. Berjemur di bawah matahari dapat meningkatkan produksi hormon serotonin. Sehingga, sangat baik untuk anak dalam membantu meningkatkan mood dan membuat anak semangat menjalani aktivitas hariannya. Sebagaimana diketahui mood anak memang mudah berubah. Mood anak setiap hari berubah sesuai kondisi kesehatan dan lingkungan. Dalam penelitian ini peneliti mengamati saat anak dalam kondisi anak mood yang baik anak akan bersemangat dalam menjalani latihan skipping dan latihan berjalan lancar. Akan tetapi ketika mood anak sedang buruk, anak akan asal-asalan atau malas menjalani latihan (Caturitayi, 2007).

Tubuh kita berada dalam kondisi optimal 3 jam setelah bangun tidur. Saat itu, darah sudah mengaliri tubuh dengan sempurna sehingga semua zat yang dibutuhkan tubuh dapat terpenuhi dengan baik. Selain itu, manfaat dilakukannya olahraga di pagi hari adalah udara yang lebih segar dan sejuk. Latihan skipping pada pagi hari yang dilakukan di luar ruangan juga lebih baik bagi tubuh karena tubuh juga terpapar sinar matahari pagi (matahari terbit - pukul 09.00) baik untuk pembentukan Vitamin D yang berguna untuk penyerapan kalsium dan fosfor (Adi, 2015).
Tabel 6.

Perbedaan cardiovasculer endurance sebelum dan sesudah latihan skipping $(n=21)$

\begin{tabular}{|c|c|c|c|c|}
\hline $\begin{array}{c}\text { Cardivasculer } \\
\text { Endurance } \\
\text { (ml/kg/me } \\
\text { nit) }\end{array}$ & Mean & $S D$ & $t$ & $P$ value \\
\hline Pretest & 42,53 & 4,43 & 5,362 & 0,000 \\
\hline Post test & 45,83 & 4,92 & & \\
\hline
\end{tabular}

Selanjutnya dilakukan uji beda antara data pre-test dengan data post-test menggunakan Simple Paired T-Test didapatkan hasil nilai $t=5,362$ dan $p$ value $=$ 0.000 ( $p$ value $<0.05$ ). Hal ini berarti Hipotesis nol (H0) ditolak dan Hipotesis alternatif (Ha) dapat diterima dan dengan demikian dapat disimpulkan bahwa terdapat pengaruh latihan skipping terhadap peningkatan cardiovascular endurance pada anak usia sekolah 10-12 tahun.

\section{Simpulan dan Saran}

Berdasarkan hasil penelitian yang sudah dilakukan pada 19 Desember 2016 - 15 Januari 2017, mengenai pengaruh latihan skipping terhadap cardiovaskular endurance anak usia 10 - 12 tahun di SD Negeri Plumbon 02 Kecamatan Suruh Kabupaten Semarang dapat diambil kesimpulan sebagai berikut:

a. Nilai cardiovaskular endurance rata-rata sebelum latihan skipping yaitu 42,53 $\mathrm{ml} / \mathrm{kg} /$ menit.

b. Nilai cardiovaskular endurance rata-rata setelah latihan skipping yaitu 45,83 $\mathrm{ml} / \mathrm{kg} /$ menit dengan mean selisih pretest dan post-test yaitu $3,3 \mathrm{ml} / \mathrm{kg} /$ menit. Sehingga nilai cardiovaskular endurance mengalami kenaikan.

c. Ada pengaruh latihan skipping terhadap cardiovaskular endurance pada anak usia 10 - 12 tahun

Adapun saran peneliti setelah dilakukannya penelitian mengenai pengaruh latihan skipping terhadap cardiovaskular endurance anak usia $10-12$ tahun di SD Negeri Plumbon 02 Kecamatan Suruh Kabupaten Semarang, yaitu:

a. Bagi Orang Tua Para orang tua dapat menambah wawasan mengenai pengaruh latihan skipping terhadap peningkatan 
cardiovascular endurance. Selain itu, diharapkan dapat menjadikan latihan skipping sebagai bentuk latihan fisik untuk meningkatkan cardiovascular endurance anak. Daya tahan jantung yang bagus sejak dini akan membuat anak memiliki kebugaran jasmani yang baik dan dapat mencegah berbagai macam penyakit di masa mendatang.

b. Bagi Kesehatan

Dalam bidang kesehatan, kiranya hasil penelitian ini dapat berguna dan dapat menjadi acuan kedepannya bagi anakanak, remaja hingga usia dewasa untuk sebuah pembelajaran program latihan untuk cardiovaskular endurance.

c. Bagi Pendidikan

Sekiranya penelitian ini menjadi masukan yang positif dalam bidang pendidikan dan terutama dalam bidang mata pelajaran Penjasorkes, latihan skipping dapat dijadikan sebagai variasi latihan fisik saat dilakukkanya mata pelajaran Penjasorkes

d. Bagi Peneliti

Peneliti selanjutnya diharapkan melakukan penelitian dengan manambahkan variasi atau inovasi dalam latihan skipping dan teknik pengukuran cardiovasculer endurance.

\section{Daftar Pustaka}

Adi D Tilong. 2015. Jam Piket Organ Tubuh. Yogyakarta. FlashBooks; $143-145$

Agustin Utari. 2007 Hubungan Indeks Massa Tubuh Dengan Tingkat Kesegaran Jasmani Pada Anak Usia 12-14 Tahun. Tesis. Semarang ; Program Pascasarjana Magister Ilmu Biomedik Program Pendidikan Dokter Spesialis I Fakultas Kedokteran Universitas Diponegoro.

Aris Setiyawan. 2015. Tingkat Daya Tahan Aerobik (Vo2 Max) Siswa Kelas Xi Tata Boga Smk Ma'arif 2 Tempel Sleman Yogyakarta.Yogyakarta ; Fakultas Ilmu Keolahragaan Universitas Negeri Yogyakarta.

Ayu Permata. 2015. Pelatihan Interval Intensitas Tinggi Lebih Meningkatkan Kebugaran Fisik Daripada Senam Aerobik High Impact Pada Mahasiswa Program
Studi D-Iii Fisioterapi Universitas Abdurrab. Tesis. Denpasar. Universitas Udayana.

Ayu Rahmayana. 2016. Perbedaan Kapasitas Aerobik Terhadap Latihan Interval Antara Jarak 60 Meter Dan 100 Meter Pada Remaja Putri. Jakarta ; Fakultas Fisioterapi Universitas Esa Unggul.

Caturitayi, dkk. 2007. Hambatan-Hambatan Dalam Mengembangkan Kecerdasan Logical/Mathematical Pada Pembelajaran Terpadu Model Webbed Berbasis Kecerdasan Jamak Di Tkit Salman Al Farisi II Yogyakarta. Phytahoras; 3.12

Faisal Yunus. 2015. Faal Paru dan Olahraga. J Respir Indo; 7. 2-3

Fandy Burhan. 2010. Pengaruh Latihan Skipping dan Shuttle Run terhadap Footwork Bulu Tangkis Usia 11-13 Tahun PB. Surya Tidar Magelang.

Femina. 2016. Fenomena Perokok Usia Anak, Saatnya Kita Bertindak!. 07 Desember 2016.http://www.femina.co.id/Famil y/fenomena-perokok-usia-anaksaatnya-kita-bertindak-

Mackenzie, B. 2016. Rockport Fitness Walking Test. $25 \quad$ Oktober 2016. https://www.brianmac.co.uk/rockport.htm

Muhajir. 2007. Pendidikan Jasmani, Kesehatan dan Rekreasi. Bandung : Yudhistira. 5657

Nabi T, Rafiq N, Qayoom O. 2015. Assessment Of Cardiovascular Fitnes $\left(\mathrm{VO}_{2}\right.$ Max) Among Medical Students By Queens Collage Step Test. International Journal of Biomedical and Advance Research. 1-3

Notoatmodjo, Soekidjo. 2010. Metodologi Penelitian Kesehatan. Jakarta ; Rineka Cipta

Nurul Istya M. 2016. Pengaruh Latihan Skipping Terhadap Kardiovaskular Endurance Pada Kelompok Cabang Olahraga Beladiri. Makassar ; Program Studi Fisioerapi Fakultas Kedokteran Universitas Hasanuddin

Reny Jayusfani, Afriwardi, Eti Yerizel. 2012. Hubungan IMT (Indeks Massa Tubuh) dengan Ketahanan (Endurance) Kardiorespirasi pada Mahasiswa Pendidikan Dokter Unand. Jurnal FK Unand. 
Soetjiningsih. 2014. Tumbuh Kembang Anak. Ed 2. Jakarta ; EGC. 14-15

Sora. 2015. Pengertian Populasi Dan Sampel Serta Teknik Sampling. 28 Oktober 2016.http://www.pengertianku.net/2 015/03/pengertian-populasi-dansampel-serta-teknik-sampling.html

Steven, Philip. 2016. Daya Tahan JantungParu. $01 \quad$ Desember 2016. http://www.fobi.or.id/index.php/tip s/25-daya-tahan-jantung-paru.

Tonang Juniarta S. 2014. Pengembangan Model Permainan Rintangan (Handicap Games) Untuk Latihan Kebugaran Jasmani Anak Usia 10-12 Tahun. Jurnal Keolahragaan ;2. 2

WHO. 2015. Global recommendations on physical activity for health. Fact Sheet Physical activity. 1-2

WHO. 2016. Physical activity. 2016. Media Centre. 1-2 